\title{
Introduction to the special issue: changing nature of work and organizations in India
}

\author{
Devi Vijay
}

Published online: 21 May 2019

(C) Indian Institute of Management Calcutta 2019

This special issue of Decision examines the changing nature of work and organizations in India. In 1991, under the mandate of the World Bank and the International Monetary Fund, as one of the "locomotives of the South" (Brazil, India, China, and South Africa), India introduced the structural adjustment program (Prashad 2013: 28), ushering in an era of neoliberal structural changes marked by intensifying globalization, financialization, and privatization (Harvey 2019). Undeniably, the primary beneficiaries of India's liberalization have been the new middle class and the business and financial elite (Crabtree 2018; Fernandes and Heller 2006). Visibly, today we have Alexas in our living rooms, e-commerce deliveries at our doorsteps, shopping malls with designer labels, and convenient flight connections to Instagram-worthy selfie spots anywhere in the world. Moreover, this epochal shift has also been characterized by the creation of new Indians, with new dreams, passions, and aspirations, and new subjectivities (Gooptu 2013). As academics in premier management institutions, we see our students increasingly join the global managerial elite, while we frequently train and consult with multinational corporate powerhouses, and are incentivized to converse in international, typically Eurocentric, research spaces.

\section{Vijay $(\bowtie)$}

Indian Institute of Management Calcutta, Kolkata, India e-mail: devivijay@iimcal.ac.in
However, as Australian documentary film-maker and journalist John Pilger noted (Pilger 2016: 36), "'Global economy' is a modern Orwellian term." Often suppressed, barely concealed, under these very structural adjustment programs is the globalization of poverty and precariousness. Moreover, while its ideological tenet of economic growth is and could be one means of poverty reduction, neoliberal India is marked by increased material inequality, elite income consolidation (Chancel and Piketty 2017), and radical asymmetries in the distribution of power and wealth (Parry 2014). As of 2017, India's capitalist story stars 101 billionaires whose wealth increased ten times over a decade, while $93 \%$ of the workforce is employed in the informal sector, with an $18 \%$ increase in informal sector participation over a decade (Himanshu 2018). The percentage of women working in private households has doubled in the twenty-first century, and 84\% (in urban areas) earn less than minimum wages (Ray and Qayum 2009). Aptly, Barbara Harriss-White (2014: 388) observes, "While it cannot be denied that capitalism creates wealth, Indian capitalism also pauperizes its workforce."

In this context, and consistent with wider global patterns, there have been dramatic transformations in labor markets, local economies, work arrangements, and organizational practices (Gooptu 2013; HarrissWhite 2014). Steadily, discourse of management, markets, and finance permeate basic, essential services such as health (Chakravarthi et al. 2017), housing 
(Chattaraj et al. 2017), and education (Varman et al. 2011). Further, this discourse materializes as labor market flexibility and work intensification (Bathini and Kandathil 2019), labor casualization, informalization (Harriss-White 2014), contractualization, and sharp distinctions between secure and insecure wage labor (Parry 2013). Certain forms of state protectionism that prevailed with the welfare state have not only been hollowed out with increased privatization but have arguably constructed new forms of corporatestate nexus that dispossess and dehumanize some of the most vulnerable citizenry (Varman and Vijay 2018).

While these transformations are consistent with wider global patterns, there are uneven geographies of globalization. Two specificities of neoliberal normativity in India are worth noting. First, these structural transformations are layered over social vectors of caste, gender, and religion (Chatterji et al. 2019; Teltumbde 2018). Second, our imaginations of progress and modernity remain colonized by Western capitalist discourse. The West holds considerable symbolic power in our education system and in the production and practice of scientific knowledge in the Indian context. Accordingly, mainstream management theories developed in the West become the "dominant lens through which Indian scholars interpret their context" (Vijay and Varman 2018: 15). But the frame of this dominant lens does not merely exhibit a reality, rather it "actively participates in a strategy of containment, selectively producing and enforcing what will count as reality... always throwing something away, always keeping something out, always derealizing and de-legitimating alternative versions of reality" (Butler 2016: xiii). Such dominant frames can and must then be disrupted in order to construct an alternative imagination.

Thus, our aim in this special issue has been to create spaces for perspectives that are less heard in mainstream academic conversations. This collection of four research articles, one speak-out essay, and one virtual roundtable examines a range of contemporary issues pertaining to domestic workers' employment conditions, national security labor, academic labor, climatechange-induced agrarian distress and digital labor platforms, and the MeToo movement. On occasion, the authors speak from their disciplines-here, management studies, sociology, public policy, and anthropology; on occasion, they traverse multiple disciplines. Theoretically, they foreground challenges of collective action, organizational dissent, precarity of neoliberal labor, migration, and the possibilities of solidarities. All, however, share certain common themes outlined below, and many of the writings shed any pretence of impartiality. As Freire eloquently stated (Freire 1998: 22),

My abhorrence of neoliberalism helps to explain my legitimate anger when I speak of the injustices to which the ragpickers among humanity are condemned. It also explains my total lack of interest in any pretension of impartiality. I am not impartial or objective; not a fixed observer of facts and happenings... And this does not necessarily mean that the observer's position is erroneous. It is an error when one becomes dogmatic about one's point of view and ignores the fact that, even if one is certain about his or her point of view, it does not mean that one's position is always ethically grounded.

Taken as a whole then, these articles raise ethically grounded concerns and provide insights into three broad themes: (a) the nature of precarity in neoliberal regimes, (b) the jarring silences and ellipses that prevail, and (c) resistance, dissent and collective action in such contexts.

\section{Nature of precarity in neoliberal regimes}

To say that life is precarious is to apprehend that a viable life depends not simply on an individual's drive to live but fundamentally on social and political conditions (Butler 2016). Lives can be rendered precarious, by treating them as lesser beings and denying them the possibilities of recognition (Butler 2004). Precarious lives can be expunged or violated, without ever being grieved.

Precariousness surfaces as a common thread across all articles, with some contributors explicitly engaging with it theoretically. Rajnish Rai's autoethnography here reveals the precarity a state official encounters when he seeks to engage in a critical discourse with the State on national security labor conditions. The neoliberal state wields sovereign power, "an unaccountable operation of power" (Butler 2004: xv), once the dissenting subject uncloaks spectacles. The sovereign power can now make life and death 
decisions bound by no constitutional constraints. More than the particularism of India's majoritarian nationalism, it is helpful to remember the marginalization of dissent beyond the immediate national context. Such marginalization of the dissenting subject is reminiscent of the targeting of Julian Assange or Chelsea Manning - such actors are denounced and stigmatized not because they engaged in violent acts, but because they exposed them. As Rai poignantly notes, "today, conscience itself has become a precarious entity."

Srinath Jagannathan and Premalatha Packirisamy engage with the vulnerabilities of academic labor which manifests in contractual positions, individualizing academic environments, and de-intellectualized research and teaching commitments. Importantly, they delineate how academic precarity is mediated by caste and gender relations. In a similar vein, Priyanshu Gupta and Vivek Nair, in their speak-out essay, lament the vulnerability of doctoral students in contemporary neoliberal universities that benchmark themselves against accreditations, journal rankings, and impact metrics. Together, the two articles interrogate the intersection of organization of knowledge in the university and the production of disposable labor. These two writings join a global chorus from academics, who contest the marketization of higher education (Parker 2014).

While there remains a need for caution and deliberation in bringing together very heterogeneous groups into the analytical category of precariousness, these studies record the different scales and socioeconomic contexts within which variations of precarity manifest (see also Schierup and Jorgensen 2016). Undeniably, neoliberalism creates precariousness across classes, exemplified by our shared vulnerability to climate change and perpetual war. Moreover, as Byung-chul Han (2017: 5) notes, "Today, everyone is an auto-exploiting labourer in his or her own enterprise... Even class struggle has transformed into an inner struggle against oneself." Yet some populations are more subject to heightened precarity and violence than others.

Rajesh Joseph, Balmurli Natrajan, and Roshni Lobo attend to domestic workers-India's second largest informal workforce-who are bound to the institution of domestic servitude that constitutes the bedrock of upper and middle-class existence. Rising urban middle- and upper-class incomes, coupled with normalized cultural markers of employing "servants" or "maids" accompany a rise in domestic work activities in India. Joseph and colleagues document domestic workers' precarity enmeshed in debt and obligations, and foreground the unique challenges of organizing workers who work in middle-class homes - a pivotal site of reproduction of labor relations. The authors provide sharp insights into the difficulty of recognizing domestic servants as "workers"; these are precarious subjects who are not quite recognizable or intelligible as subjects.

Migration is a key mechanism by which capitalism structures precarity. Capitalism supports migration in the name of personal liberty and human rights (Streeck 2016). Yet, the breakdown of community networks, and economic instability, renders a docile workforce, grateful for employment, conscripted into contracts that do not guarantee minimum wages and employment protections, hesitant to mobilize collectively, thus lacking political capacity (Streeck 2016). Surie and Sharma connect the dots between climate-changeinduced migration and digital labor markets, in their account of how Ola and Uber provide short-term adaptive solutions to migrant farmers.

Sanjana Pegu's virtual roundtable curates the experiences of five women activists on their work with the feminist movement, and gender-based violence. Pegu sheds light on the significance of MeToo movement in India, and the specific precarities confronting those at higher risk of gender-based violence in Dalit, Bahujan and Adivasi communities, and regions such as the northeastern states marked by long histories of conflict and militarization. Pegu's dialogue interrogates the act of resistance in the recent \#MeToo movement to ask what politically can be made of assault and violence, besides calls for vengeance and humiliation. Sanjana, serving as an interlocutor here, reflects on the silences on workingclass sexual harassment, and the implications of the caste-capitalist-patriarchy nexus.

\section{Silences, erasures and magic}

Precariousness is normalized in several ways. First, there is the appropriation of the media and academiatwo institutions with abundant resources to critically examine this new social order. Both have played vital roles in extolling India's ambitions as it muscles its way to becoming a global superpower, and have been 
complicit in reproducing hegemonic discourses, either by explicitly aligning with dominant frames, or through silence. Pointing to the machinations of mainstream media, Pegu delineates how media engages in upper-class narratives of sexual violence, silencing the working classes and other marginalized voices. Similarly, Jagannathan and Packirisamy, and Gupta and Nair describe the shrinking, alienating spaces for critical engagement in academia.

A second key way by which precariousness is normalized is by depriving individuals of institutional support and collective solidarities. Coping with precarity then must be resolved through self-help, optimism, and enterprise. Both articles on academic labor, and the roundtable on the MeToo movement, surface these tensions confronted by individuals who must resort to improvised responses and stop gap solutions, in the absence of collectives. In this milieu, collective action is perceived as useless. Suppression of resistance then dons two guises. First, resistors are disparaged: Those who resist, or form collectives, are non-productive, like the "excuseniks" who protested the Iraq invasion, or "anti-national" or irrational if you challenge majoritarian rhetoric. Second, any form of dissent, to capitalist expansion, to war, or toxicity, is equated with dissent to "progress," "development," and growth, indeed dissent to national sovereignty itself. The public sphere is then "constituted in part by what cannot be said, and what cannot be shown," and only some subjects appear as viable actors (Butler 2004: xvii).

A third insidious normalization of precariousness today is by distractions and spectacles. Rai points to the State's magic rituals, by which spectacles to confound the citizenry are staged. Indeed, economists Prabhat Patnaik and Amartya Sen, speaking at a recent session at the World Leaders Forum, Columbia University, noted that magic appeared to be a key element producing distractions and falsehoods, as ubiquitous in Indian polity today (The Wire 2019).

In the process, all violence is shrouded and normalized. Thus, verses from revolutionary poet Faiz Ahmed Faiz's "Lahu Ka Suragh" (Trace of Blood ${ }^{1}$ resonate louder today, as he laments,

\footnotetext{
1 Translation from Anthems of Resistance, by Mir and Mir (2016).
}

Kahin nahin hai kahin bhi nahi lahu ka suragh (Nowhere, nowhere is any trace of the blood) ...Kisi to bahr-e sama' at na waqt tha na dimagh (None had the ability to listen, nor the time, nor the patience)

Na muddaí na shahadat hisaab paak hua... (No plaintiff stepped forward, no one bore witness, and so the account was closed)

\section{Resistance, dissent and collective action}

Yet, every once in a while, Faiz's plaintiff steps up, unmasks the shroud that conceals bloodstains, and refuses to close the account. Rajnish Rai's autoethnography is one such endeavor. Rai reveals to us through his exercise of autoethnography, how introspection, writing letters, indeed, writing self, become political acts. While the State here creates a spectacle by mobilizing fear, that others (sometimes Muslims, sometimes Naxals, sometimes separatists, always the marginalized), will inflict harm on the nation, Rai mobilizes his vulnerability to write, deliberate, question, and dissent, and in doing so, performs a singular act of courage that exposes the State's spectacle. In a similar vein, Jagannathan and Packirisamy, leverage the autoethnography to write the personal into the political.

Joseph, Natrajan, and Lobo trace domestic workers' collectivization in Bangalore. They meticulously record the processes of formation of "labor NGO," and the "place" for organizing the union. As much as apartment complexes introduce new forms of surveillance, and cordon off organizing, organizers reframe the apartment as a factory gate, as a place of organizing for workers' rights. Domestic workers, increasingly conscious of their rights, demanding minimum wages and bonus (instead of gifts), remind us of the long histories of solidaristic struggles that have alternative world-making possibilities. As Christina Thomas Dhanraj, one of Sanjana's respondents, exhorts, "Marginalised women in India have been organising, mobilising, and working on the ground for a very long time... How about joining us, instead of 'including' us?" 


\section{Conclusion}

The articles curated in this special issue bear witness to changing nature of work and organization in India. They do so, through both theoretical and methodological contributions. They also leave us with new directions and unanswered questions for work and organizations studies. In these moments of heightened vulnerability and precariousness, what forms does political deliberation take? Within deeply individualizing structures, how do we find common ground and forge collectives? What new methodologies and social theories can we turn to? How do we construct an alternative imagination? This special issue has sought to open up debates, to unconceal deeper transformations, and to rupture silences in the world around us. The point, however, is to change it.

\section{References}

Bathini DR, Kandathil GM (2019) An orchestrated negotiated exchange: Trading home-based telework for intensified work. J Bus Ethics 154(2):411-423

Butler J (2004) Precarious life: The powers of violence and mourning. Verso, London

Butler J (2016) Frames of war: When is life grievable? Verso Books, New York

Chakravarthi I, Roy B, Mukhopadhyay I, Barria S (2017) Investing in Health. Economic \& Political Weekly 52(45):51

Chancel L, Piketty T (2017) Indian income inequality, 1922-2014: From British Raj to Billionaire Raj? CEPR discussion paper no. DP12409. Available at SSRN: https:// ssrn.com/abstract=3066021. Accessed 17 Apr 2019

Chattaraj D, Choudhury K, Joshi M (2017) The Tenth Delhi: Economy, politics and space in the post-liberalisation metropolis. Decision 44(2):147-160

Chatterji A, Hansen TB, Jaffrelot C (2019) Majoritarian state: How Hindu nationalism is changing India. Harper Collins India, New Delhi

Crabtree J (2018) The Billionaire Raj: A journey through India's new gilded age. Tim Duggan Books, New York

Fernandes L, Heller P (2006) Hegemonic aspirations: New middle class politics and India's democracy in comparative perspective. Critical Asian Studies 38(4):495-522

Freire P (1998) Pedagogy of the heart. Bloomsbury Publishing, New York
Gooptu N (ed) (2013) Enterprise culture in neoliberal India: Studies in youth, class, work and media. Routledge, London

Han BC (2017) Psychopolitics: Neoliberalism and new technologies of power. Verso, New York

Harriss-White B (2014) The Dynamic Political Economy of Persistent Poverty. In: Gooptu N, Parry J (eds) Persistence of poverty in India. Social Science Press, New Delhi

Harvey D (2019) Spaces of global capitalism, 3rd edn. Verso, New York

Himanshu (2018) India inequality report 2018: Widening gaps. Oxfam India, New Delhi

Mir AH, Mir R (2006) Anthems of resistance: A celebration of progressive Urdu poetry. India Ink, New Delhi

Parker M (2014) University Ltd: Changing a business school. Organization 21(2):281-292

Parry J (2013) Company and contract labour in a central Indian steel plant. Economy and Society 42(3):348-374

Parry J (2014) Introduction: On the Persistence of Poverty in India. In: Gooptu N, Parry J (eds) Persistence of poverty in India. Social Science Press, New Delhi

Pilger J (2016) The new rulers of the world. Verso Books, New York

Prashad V (2013) The poorer nations: A possible history of the global south. Verso, New York

Ray R, Qayum S (2009) Cultures of servitude: modernity, domesticity, and class in India. Stanford University Press, Palo Alto

Schierup C, Jorgensen MB (2016) An introduction to the special issue. Politics of precarity: Migrant conditions, struggles, and experiences. Critical Sociology 42(7-8):947-958

Streeck W (2016) How will capitalism end? Essays on a failing system. Verso, New York

Teltumbde A (2018) Republic of caste: Thinking equality in the time of neoliberal Hindutva. Navayana, New Delhi

The Wire (2019) 'Modi magic': Amartya Sen says constant distractions key to BJP Govt. Accessed from https:// thewire.in/politics/amartya-sen-prabhat-patnaik-elections2019-bjp-modi on Sunday, 28th April 2019

Varman R, Vijay D (2018) Dispossessing vulnerable consumers: Derealization, desubjectification, and violence. Marketing Theory 18(3):307-326

Varman R, Saha B, Skålén P (2011) Market subjectivity and neoliberal governmentality in higher education. Journal of Marketing Management 27(11-12):1163-1185

Vijay D, Varman R (2018) Introduction: Undoing boundaries. In: Vijay D, Varman R (eds) Alternative organisations in India: undoing boundaries. Cambridge University Press, New Delhi, pp 1-25

Publisher's Note Springer Nature remains neutral with regard to jurisdictional claims in published maps and institutional affiliations. 